\title{
Cardioprotective Effects of Aqueous Extract of Ripped Musa paradisiaca Peel in Isoproterenol Induced Myocardial Infarction Rat Model
}

\author{
Kolawole Yusuf Suleiman ${ }^{1, *(\odot)}$, Emmanuel Oladipo Ajani ${ }^{2 \oplus}$, Khalid Talha Biobaku ${ }^{3}$, \\ Babatunde Sammuel Okediran $^{1 \odot}$, Mistura Oyebisi Azeez ${ }^{1 \odot}$, Ganiu Akorede Jimoh $^{3 \odot}{ }^{\circledR}$ Abdulfatai Aremu $^{3 \odot}$, \\ Akeem Olayiwola Ahmed ${ }^{4}$
}

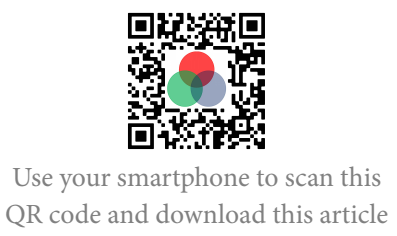

${ }^{1}$ Department of Veterinary Physiology and Biochemistry, Faculty of Veterinary Medicine, University of Ilorin, P.M.B. 1515, Ilorin Nigeria

${ }^{2}$ Phytomedicine, Toxicology and Drug Development Labouratory, Department of Medical Biochemistry and

Pharmacology, School of Basic Medical Sciences, Kwara State University, Malete, P.M.B. 1530, Ilorin Nigeria

${ }^{3}$ Department of Veterinary Pharmacology and Toxicology, Faculty of Veterinary Medicine, University of Ilorin, P.M.B. 1515, Ilorin Nigeria

${ }^{4}$ Department of Veterinary Microbiology, Faculty of Veterinary Medicine, University of Ilorin, P.M.B. 1515, Ilorin Nigeria

\section{Correspondence}

Kolawole Yusuf Suleiman, Department of Veterinary Physiology and Biochemistry, Faculty of Veterinary Medicine, University of Ilorin, P.M.B. 1515, Ilorin Nigeria

Email: suleiman.ky@unilorin.edu.ng

History

- Received: Aug 30, 2021

- Accepted: Sep 29, 2021

- Published: Oct 29, 2021

DOI : 10.15419/bmrat.v8i10.699

\section{Check for updates}

Copyright

(c) Biomedpress. This is an openaccess article distributed under the terms of the Creative Commons Attribution 4.0 International license.

\begin{abstract}
Background: Myocardial infarction (MI) is the leading cause of cardiovascular deaths worldwide. Musa paradisiaca has been reported to contain secondary metabolites with antioxidant properties. This study investigated the possible cardioprotective effects of aqueous ripped Musa paradisiaca peel extract (MPPE) in an isoproterenol (ISO)-induced MI rat model relative to aspirin as a standard drug. Methods: The MPP was extracted in distilled water using cold extraction; thereafter, MPPE was screened for secondary metabolites using standard biochemical methods. Investigation on the acute toxicity of MPPE was done in compliance with ARRIVE guidelines. Cardioprotective effects of the extract were established using biochemical assays (ELISA technique), an electrocardiogram, and a histological examination. We analyzed the data using a graphical prism version 5.03. Results: The screening of MPPE revealed the presence of secondary metabolites, including flavonoids and phenols. The LD 50 was above $5000 \mathrm{mg} / \mathrm{kg}$. Rats administered ISO developed $\mathrm{Ml}$ evidenced by increased cardiac troponin-I (cTn-I), pro-inflammatory cytokines (IL-1 $\beta$, IL-6, and TNF- $\alpha$ ), malondialdehyde, and ST segment elevation on the ECG. Further, there was a reduction in antioxidant enzymes and membrane-bound $\mathrm{Na}^{+} / \mathrm{K}^{+}$ATPase activities. Pre-treatment with MPP promoted restoration of cardiomyocytes with no side effect compared to aspirin. Significantly, it increased CAT, SOD, and Na+/K+ ATPase activities and decreased pro-inflammatory cytokines, MDA, and CTn-I, thereby reducing the elevation of ST-segment on the ECG to near normal. Results from the histopathological study support the cardioprotective effects of MPP. Conclusion: The MPP confers protection to the myocardium through its antioxidant and anti-peroxidation properties that act as possible mechanisms in ISO-induced $\mathrm{Ml}$ in rat models.
\end{abstract}

Key words: Anti-inflammatory, Antioxidant, Isoproterenol, Musa paradisiaca, Myocardial infarction

\section{INTRODUCTION}

Myocardial infarction (MI), characterized by the hypoxic state of myocardial tissue sequel to uneven perfusion of coronary blood supply compared to demand, is a leading cause of cardiovascular morbidity and mortality in men ${ }^{1}$. MI causes myocardial ischemic injury and damage to the cardiomyocytes. The repair of damaged hearts in patients is challenging due to the limited ability of the cardiomyocytes to regenerate post-mitotically. Prolonged evident ischemia in chronic MI eventually leads to permanent myocardial cell injury or death ${ }^{2}$.

Citizens from low and middle-income countries, such as sub-Sahara Africa, including Nigeria, are more vulnerable to MI, with an increasing number of cases recorded in adults owing to habits and lifestyle such as excessive consumption of junk food, a lack of physical exercise, an over-labored working condition, and poverty ${ }^{3}$.

Previous reports suggest that the accumulation of reactive oxygen species (ROS) causing oxidative changes to the macro-molecules during ischemic damage played a pivotal role in the pathogenesis of MI with the deleterious consequence, evidenced by the elevation of cardiac troponin-I (cTn-I), the upregulation of the pro-inflammatory cytokines interleukine- 1 (IL-1 $\beta$ ) and interleukine-6 (IL-6), and tissue necrotic factor (TNF- $\alpha)^{2}$. In addition, MI manifests by impaired sodium-potassium ATPase activity and electrocardiogram alterations together with histopathology changes ${ }^{4,5}$.

Therapy with agents possessing antioxidant properties is of great interest due to the overwhelming evidence implicating oxidative stress sequel to increased production of free radicals during the pathogenesis of $\mathrm{MI}^{6}$. However, the limitations (such as a high level 
of toxicity and low aqueous solubility) observed following the use of synthetic antioxidants in preventing cardiovascular diseases have shifted the attention of researchers to the use of naturally derived antioxidants, owing to their high safety margin, cultural acceptability, and promised efficacy ${ }^{7}$.

Banana is the common term used to refer to several hybrids in the genus Musa. Plantain, Musa paradisiaca, is considered a good food source of natural antioxidants against cancer and heart disease ${ }^{8}$. It is widely consumed without apparent toxic effects, and its antioxidant properties have been traced to its presence of vitamin $\mathrm{C}$, vitamin $\mathrm{E}, \beta$-carotene, and dopamine. The report showed that peels of Musa paradisiaca constitute about $40 \%$ of the total weight of the fresh fruit and displayed reasonable antimicrobial and antioxidant activities in both ethyl acetate and water-soluble extracts ${ }^{\mathbf{9 , 1 0}}$. In addition, several secondary metabolites (flavonoids, phenols, tannins, alkaloids, and glycosides) have also been isolated from plantain peels suggesting its antioxidant and anti-inflammatory effects ${ }^{8}$.

For over 25 years, aspirin (acetylsalicylic acid) has been known for its role in preventing MI and ischemic stroke through its anti-thrombotic effect ${ }^{11}$. Aspirin displays an antiplatelet effect at low doses, thus prolonging bleeding time by selectively inhibiting cyclooxygenase (COX)-I, an enzyme that produces the platelet antagonist thromboxane A2, and acting as an effective vasoconstrictor ${ }^{12}$. Based on the chemical constituent and reported activities of plantain peel, the present study aims to evaluate the cardioprotective effects of the aqueous extract of riped Musa paradisiaca peels following isoproterenol-induced myocardial infarction.

\section{MATERIAL AND METHODS MATERIAL}

A commercial grade standard of H906 (25 g) marketed as Isoprenaline $\mathrm{HCl}$ (98\% HPLC) was obtained from AK Scientific, Inc, USA. Aspirin, the standard drug used, was procured from Bioraj pharmaceuticals, Nigeria. Pro-inflammatory cytokines (TNF- $\alpha$, IL- $1 \beta$ and IL-6) and cTn-I test kits were obtained from Junjiang Inter. Bldg Shanghai, China, and Calbiotech, California, USA, respectively. Other reagents and chemicals used were of analytical grades.

\section{Plant material and extraction}

Freshly ripped peels of Musa paradisiaca were collected from a major food canteen at Malete, Kwara
State, Nigeria. The plant was identified at the herbarium of the Department of Plant Biology, University of Ilorin, Nigeria, and the voucher specimen (UIL/001/2019/1381) was deposited at the herbarium for reference purposes. After rinsing in distilled water, the peels were air-dried to a constant weight in the laboratory at room temperature $\left(25 \pm 2.0^{\circ} \mathrm{C}\right)$ and pulverized to a powdered form using a kitchen blender (Nakai Japan, China). The powdered samples were kept in an airtight container until ready for use. One kilogram of powdered Musa paradisiaca peels was extracted in 5 Litres (L) of distilled water using the cold maceration method ${ }^{\mathbf{1 3}}$. Thereafter, the solution was filtered with Whatman No 1 filter (Sigma Aldrich, St. Louis, MO, USA). The filtrate was concentrated invacuo, using a hot air oven (Surgifield Medical, Germany) set at $30^{\circ} \mathrm{C}$ and thereafter preserved at $4{ }^{\circ} \mathrm{C}$ in a refrigerator until required for use. The extract was subjected to GC-MS. The Percentage yield (22.4 $\%)$ was determined, after which the extract was reconstituted with distilled water to a final concentration of $200 \mathrm{mg} / \mathrm{mL}$.

\section{Phytochemical Screening for Secondary Metabolites}

The Musa paradisiaca peel extract was evaluated for the presence of secondary metabolites by using standard methods ${ }^{14}$.

\section{Determination of Bioactive compounds con- tained in Musa paradisiaca peels using GC- MS}

Bioactive compounds contained in the extract were analyzed in a GC-MS (Shimadzu, Kyoto) QP2010S that was fitted with a $1.4 \mu \mathrm{m}$ column Rxi-5sil MS 30meter length, $0.25 \mu \mathrm{m}$ film thickness, and $0.25 \mathrm{~mm}$ inner diameter. The carrier gas was helium with a flow rate of $0.98 \mathrm{ml} / \mathrm{min}$, column temperature $80^{\circ} \mathrm{C}$, initial temperature $70^{\circ} \mathrm{C}$, injector temperature $260{ }^{\circ} \mathrm{C}$, and detector temperature $300{ }^{\circ} \mathrm{C}$. The programmed linear temperature varied from 70 to $280^{\circ} \mathrm{C}$ at a rate of $10^{\circ} \mathrm{C} / \mathrm{min}$, operating in electron impact mode. The samples were injected in splitless mode. The interface temperature was kept at $280^{\circ} \mathrm{C}$. Oven temperature programming was varied from $80^{\circ} \mathrm{C}$ to $260^{\circ} \mathrm{C}$ at $10^{\circ} \mathrm{C} / \mathrm{min}$. The pressure of the carrier gas was kept at $63.6 \mathrm{kPa}$. The individual bioactive compounds were identified using the NIST 11 and WILEY 8 library based on the RT. Consequently, the name, molecular weight (MW), and structure of the components of the test materials were ascertained ${ }^{15}$. 


\section{Experimental animals}

A total of 48 apparently healthy male Wistar rats (250 - $330 \mathrm{~g}$ ) were acquired from an experimental animal unit of the Department of Veterinary Pharmacology and Toxicology, University of Ilorin, Nigeria. The rats were distributed at random into 6 polypropylene cages (8 animals each) lined with wood shavings, renewed every $24 \mathrm{~h}$. The animals were given access to pelletized vital feed (UAC, Nigeria) while water was provided ad libitum. Optimum temperature and humidity were maintained at $28 \pm 2{ }^{\circ} \mathrm{C}$ and $65 \pm 10 \%$, respectively.

\section{Acute toxicity testing}

The median lethal dose $\left(\mathrm{LD}_{50}\right)$ was determined in accordance with the Organization of Economic Cooperation Development guidelines by a standard twophase approach described by Lorke ${ }^{16}$. In the first phase, nine apparently healthy male Wistar rats (270 - $310 \mathrm{~g}$ ) were distributed at random into 3 groups of 3 animals. The rats had fasted for 12 hours. Animals in each group (groups 1, 2, and 3) were given an aqueous extract of Musa paradisiaca peels (MPP) orally, at 10,100 and $1000 \mathrm{mg} / \mathrm{kg}$ body wt. respectively. Next, the rats were closely observed for 48 hours for signs of mortality or toxicity. Three rats were individually separated into 3 groups in the second phase of the approach. A rat in each group (groups 4, 5, and 6) was orally administered with $M P$ extract at 1600 , 2900 , and $5000 \mathrm{mg} / \mathrm{kg}$ body wt. respectively. They were later monitored from the first 24 hours until 14 days for possible toxicity signs (sedation, salivation, lethargy, and muscular weakness) and mortality. The estimated value of $\mathrm{LD}_{50}$ was thereafter determined by the previously described method ${ }^{13}$.

\section{Induction of myocardial infarction in rats us- ing isoproterenol}

Myocardial infarction was induced in this study by a twice subcutaneous injection of isoproterenol hydrochloride ( $85 \mathrm{mg} / \mathrm{kg}$ body wt.) of $20 \mathrm{mg} / \mathrm{ml}$ concentration at a 24 -hour intervals as previously described $^{4}$ on days 15 and 16 of the study. The resultant elevation of cardiac troponin-I (cTn-I) in rats confirmed the occurrence of myocardial infarction.

\section{Experimental Design}

A total of 48 rats were used in this 16-day study. The animals were assigned at random into 6 groups $(n=$ 8) and treated as follows:

Group 1 (normal group): Rats were administered 1 $\mathrm{ml}$ of distilled water orally for 16 days.
Group 2 (model group): Myocardial infarction was induced by subcutaneous injection of isoproterenol ( $85 \mathrm{mg} / \mathrm{kg}$ body wt.) at 24-hour intervals on days 15 and 16 of the study.

Groups 3, 4, 5, and 6 (preventive groups): For 14 days, rats in groups 3,4 , and 5 were pre-treated with Musa paradisiaca peel extract (100, 200, and 400 $\mathrm{mg} / \mathrm{kg}$ body wt. respectively). Also, rats in group 6 were pre-treated with aspirin ( $30 \mathrm{mg} / \mathrm{kg}$ body wt.) for 14 days. Myocardial infarction was then induced with a twice subcutaneous injection of isoproterenol (85 $\mathrm{mg} / \mathrm{kg}$ body wt.) at 24-hour intervals on days 15 and 16 of the study.

Next, the rats were anesthetized using ketamine (100 $\mathrm{mg} / \mathrm{kg}$, intramuscular, i.m.) and xylazine $(10 \mathrm{mg} / \mathrm{kg}$, i.m.) on day 17 after fasting for 24 hours. Electrocardiogram readings of all rats were then taken, after which blood was withdrawn from all the rats by cardiac puncture into disposable blood collecting tubes devoid of anticoagulant (Shandong Medical Instrument Co., Ltd, Zibo, China). The blood samples were allowed to clot within 2 hours at $37^{\circ} \mathrm{C}$, followed by centrifugation for 15 minutes at $1000 \times g$ to obtained serum. The sera obtained as supernatants were collected using a plastic pipette into another sterile sample bottle. The rats were later sacrificed by cervical dislocation. The heart tissues were immediately harvested, rinsed in phosphate buffer solution, PBS (0.01 $\mathrm{M}$ and $\mathrm{pH} 7.4)$ to remove excess blood, and then weighed. The tissues were homogenized in PBS ( $\mathrm{pH}$ 7.4) using a mortar and pestle and then thawed at 8 ${ }^{\circ} \mathrm{C}$, after which they were centrifuged at $2000 \times g$ for 20 minutes to give tissue homogenates. The serum and tissue homogenates were used to carry out biochemical assays as previously described ${ }^{17}$.

\section{Estimation of Electrocardiogram}

On day 17 of the study, ketamine (100 mg/kg, i.m.) and xylazine $(10 \mathrm{mg} / \mathrm{kg}, \mathrm{i} . \mathrm{m}$.) were used to anesthetize the rats. The electrodes from EDAN (the ECG machine connected to the laptop) (Heal force biotech, Shanghai, China) were then fixed to the rat's forelimbs (skin above the elbow), hind limbs (just above stifle joint), and the heart ${ }^{18}$. On paper, the ECG recordings were produced using speed and sensitivity of $50 \mathrm{~mm} / \mathrm{s}$ and $10 \mathrm{~mm} / \mathrm{mv}$ respectively from the experimental animals, and ECG wave alterations were noted.

\section{Biochemical assays}

Serum levels of cardiac troponin-I (cTn-I) and the pro-inflammatory cytokines (TNF- $\alpha$, IL- $1 \beta$ and IL-6) were estimated by the Enzyme-Linked Immunosorbent Assay (ELISA) technique using the 
standard kit (Calbiotech, California, USA, and Junjiang Inter. Bldg Shanghai, China) in accordance with manufacturer's instructions. The sodium-potassium ATPase activities in the tissue homogenate were measured by estimating the level of phosphorus liberated from the test samples ${ }^{19}$. The serum activities of superoxide dismutase (SOD) and Catalase (CAT) were determined according to the previously described method $^{20}$. Serum lipid peroxide activities were determined by the previously described method ${ }^{21}$. Also, serum electrolytes $\left(\mathrm{Na}^{+}, \mathrm{K}^{+}, \mathrm{Ca}^{2+}\right.$, and $\left.\mathrm{Cl}^{-}\right)$levels were determined following previously described protocols ${ }^{22}$.

\section{Histopathological Examination}

The hearts were washed with normal saline immediately after harvest and then fixed in $10 \%$ buffered neutral formalin, after which the heart tissues and coronary arteries were embedded in paraffin. After this, they were sectioned, stained (hematoxylin and eosin stain), and examined under a light microscope $(x 100)^{23}$. The slides were observed for evidence of inflammatory cells infiltration, necrosis, and edema.

\section{Statistical Analysis}

The data were expressed as mean \pm standard deviation and subjected to one-way analysis of variance (ANOVA) followed by Dunnett's multiple comparison test using Graphical prism version 5.03 (Graphical Software, San Diego, California, USA). The value of $p<0.05$ was considered a significant difference between and within groups and was denoted by letters.

\section{Ethical statement}

The experimental protocols were conducted in compliance with principles and guidelines of the ARRIVE guideline Faculty of Veterinary Medicine, the University of Ilorin Committees on Animal Use and Care (FVER/007/2019) and following the principles of laboratory animal care (NIH, 2011) guidelines.

\section{RESULTS}

\section{Testing of acute toxicity}

Rats in phases 1 and 2 administered with aqueous Musa paradisiaca peel extract of varying doses showed no toxicity signs and mortality during the monitoring period of 14 days (Table 1). In addition, at postmortem, no gross lesion was noticed in the tested rats.

\section{Secondary Metabolites Revealed by Phyto-} chemical screening

From our study, the presence of some secondary metabolites was evidenced following the phytochemical screening. These include flavonoids, phenolics, saponins, tannins, steroids, anthocyanins, glycosides, triterpenes, and alkaloids. However, coumarins, terpenoids, and phlorotannins were not detected (Table 2).

\section{Major bioactive compounds identified by GC-MS analysis}

A total of 23 major peaks were revealed by the GC-MS chromatogram of aqueous Musa paradisiaca peels (Figure 1). The identified compounds are presented with their peak, retention time (RT), area (\%), molecular formula, and molecular weight (Table 3). The (Z,Z,Z) 9,12,15-Octadecatrien-1-ol and nHexadecanoic acid showed maximum percentage. The compounds that showed moderate percentage include Phytol, Methyl ester 9,12,15-Octadecatrienoic acid, Tetradecamethyl Cyclopentasiloxane, and Methyl palmitate. The compounds 1-methyl-3-(1methyl ethyl) benzene and 2,3-dihydrobenzofuran showed a minimum percentage.

\section{Effect of treatment on serum cardiac troponin-I (cTn-I)}

Isoproterenol (ISO) treated group (model group) showed a significantly $(\mathrm{P}<0.05)$ elevated serum troponin-I (cTn-I) concentration compared to the normal control group (Figure 2 and Table 4). A group pre-treated with aspirin at $30 \mathrm{mg} / \mathrm{kg}$ body wt. revealed significantly $(\mathrm{P}<0.05)$ lowered serum activities of cTn-I when compared to the model group. Groups 3 and 4 given 100 and $200 \mathrm{mg} / \mathrm{kg}$ body wt. of the extract respectively showed an elevated mean serum cTn-I concentration compared to the control group. Groups pre-treated with $400 \mathrm{mg} / \mathrm{kg}$ body wt. extract showed significantly $(\mathrm{P}<0.05)$ reduced levels of cTn-I as compared to the model group. The levels of cTn-I in groups pre-treated with the extract and aspirin at 400 and $30 \mathrm{mg} / \mathrm{kg}$ body wt. respectively showed no significant change $(\mathrm{P}>0.05)$ when compared to the normal control group.

\section{Effect of treatment on $\mathrm{Na}^{+} / \mathrm{K}^{+}$ATPase ac- tivity in cardiomyocytes homogenate}

The cardiomyocyte's homogenate activities of $\mathrm{Na}^{+} / \mathrm{K}^{+}$ATPase in the model group were significantly $(\mathrm{P}<0.05)$ lowered compared to the normal control group (Figure 3 and Table 4). Groups 3 


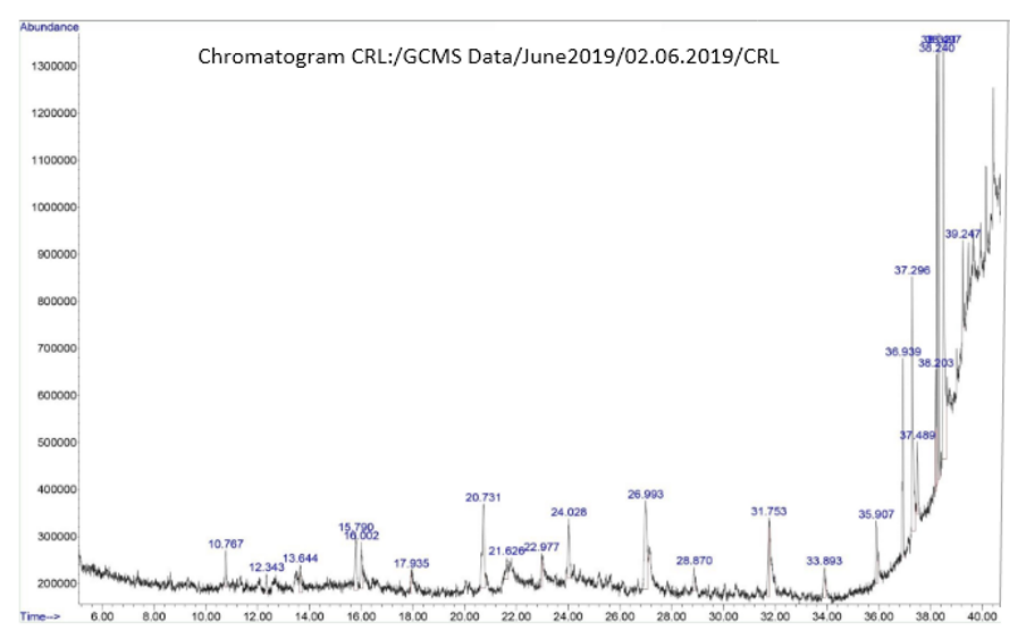

Figure 1: Chromatogram of aqueous Musa paradisiaca peels using GC — MS. https://doi.org/10.6084/m9.f igshare.16903783.v1

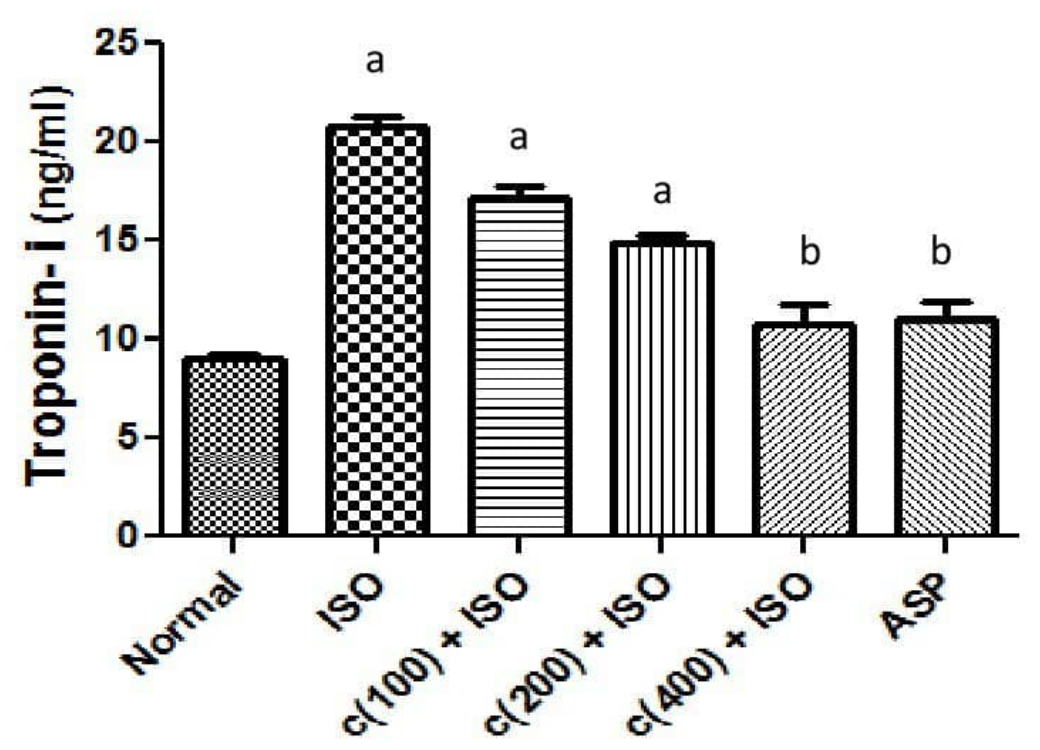

Figure 2: Effect of aqueous extract of Musa paradisiaca peels on serum cardiac troponin-I in isoproterenol induced myocardial infarcted rats. The data are expressed as mean $\pm S D$ and analyzed using one-way analysis of variance (ANOVA) and later subjected to Dunnett's post hoc test for multiple comparisons. The expressed significant differences were considered at $\mathrm{p}<0.05$. ${ }^{a} \mathrm{p}<0.05$, when compared to normal control; ${ }^{b} \mathrm{p}<0.05$, when compared to ISO group $(n=8)$. https://doi.org/10.6084/m9.figshare.16903798.v1 


\begin{tabular}{|c|c|c|c|c|c|}
\hline Phase & $\begin{array}{l}\text { Number of } \\
\text { rats }\end{array}$ & Weight of rats (g) & $\begin{array}{c}\text { Dose } \\
(\mathrm{mg} / \mathrm{mg})\end{array}$ & $\begin{array}{l}\text { Signs of toxicity } \\
\quad(\text { OTS/HR })^{*}\end{array}$ & $\begin{array}{l}\text { Mortality } \\
(\mathrm{DR} / \mathrm{SR})^{*}\end{array}$ \\
\hline \multirow[t]{9}{*}{1} & 3 & 260 & 10 & $0 / 3$ & $0 / 3$ \\
\hline & & 271 & & & \\
\hline & & 310 & & & \\
\hline & 3 & 283 & 100 & $0 / 3$ & $0 / 3$ \\
\hline & & 286 & & & \\
\hline & & 256 & & & \\
\hline & 3 & 315 & 1000 & $0 / 3$ & $0 / 3$ \\
\hline & & 270 & & & \\
\hline & & 293 & & & \\
\hline \multirow[t]{3}{*}{2} & 1 & 325 & 1600 & $0 / 1$ & $0 / 1$ \\
\hline & 1 & 265 & 2900 & $0 / 1$ & $0 / 1$ \\
\hline & 1 & 275 & 5000 & $0 / 1$ & $0 / 1$ \\
\hline
\end{tabular}

OTS: observed toxicity signs, HR: healthy rats, DR: deceased rats, SR: survived rats

Table 2: Phytochemical screening of aqueous extract of Musa paradisiaca peels

\begin{tabular}{lc}
\hline Chemical constituents & Indications \\
\hline Saponin & $10.78 \pm 0.04$ \\
Tannins & $5.77 \pm 0.25$ \\
Phenolics & $13.12 \pm 0.77$ \\
Phlebatannin & Not detected \\
Steroids & $99.40 \pm 0.75$ \\
Flavonoids & $209.20 \pm 0.39$ \\
Coumarins & Not detected \\
Anthocyanins & $0.17 \pm 0.01$ \\
Terpenoids & Not detected \\
Glycosides & $4.40 \pm 0.44$ \\
Triterpenes & $120.90 \pm 9.33$ \\
Alkaloids & $6.47 \pm 0.27$ \\
\hline Da
\end{tabular}

Data represent mean $\pm \mathrm{SD}$ of three determinations

and 4 given 100 and $200 \mathrm{mg} / \mathrm{kg}$ body wt. extract respectively showed a dose-dependent elevation of $\mathrm{Na}^{+} / \mathrm{K}^{+}$ATPase levels compared to the model group. The levels of $\mathrm{Na}^{+} / \mathrm{K}^{+}$ATPase in groups pre-treated with the extract and aspirin at 400 and $30 \mathrm{mg} / \mathrm{kg}$ body wt. respectively showed significantly higher $\mathrm{Na}^{+} / \mathrm{K}^{+}$ATPase activities $(\mathrm{P}<0.05)$ compared to the model group but exhibited no significant difference $(\mathrm{P}>0.05)$ compared to the normal control group.
Effect of treatment on serum antioxidant enzymes (catalase, CAT, and superoxide dismutase, SOD) and lipid peroxidation (malondialdehyde, MDA) activities

Antioxidant enzymes were lowered $(P<0.05)$ in the model group compared to the normal group for serum levels of CAT and SOD (Table 5). In the group pre-treated with ASP at $30 \mathrm{mg} / \mathrm{kg}$ body wt., serum levels of these antioxidant enzymes were 


\begin{tabular}{|c|c|c|c|c|c|}
\hline Peak & $\begin{array}{c}\text { Retention } \\
\text { Time }\end{array}$ & $\begin{array}{c}\text { Area } \\
\%\end{array}$ & $\begin{array}{l}\text { Molecular } \\
\text { formula }\end{array}$ & $\begin{array}{c}\text { Molecular } \\
\text { weight } \\
(\mathrm{g} / \mathrm{mol})\end{array}$ & Name of the compound \\
\hline 1 & 10.767 & 1.73 & $\mathrm{C}_{2} \mathrm{H}_{4} \mathrm{O}$ & 44.05 & Oxirane \\
\hline 2 & 12.343 & 0.90 & $\mathrm{C}_{10} \mathrm{H}_{14}$ & 134.22 & 1-methyl-3-(1-methylethyl) benzene \\
\hline 3 & 13.644 & 1.29 & $\mathrm{C}_{10} \mathrm{H}_{14}$ & 134.22 & 1,2,3,4-tetramethylbenzene \\
\hline 4 & 15.790 & 3.24 & $\mathrm{C}_{10} \mathrm{H}_{8}$ & 128.17 & Naphthalene \\
\hline 5 & 16.002 & 2.58 & $\mathrm{C}_{5} \mathrm{H}_{10} \mathrm{~N}_{2} \mathrm{O}$ & 114.15 & 1-Piperazinecarboxaldehyde \\
\hline 6 & 17.935 & 0.72 & $\mathrm{C}_{8} \mathrm{H}_{8} \mathrm{O}$ & 120.15 & 2,3-dihydrobenzofuran \\
\hline 7 & 20.731 & 6.00 & $\mathrm{C}_{9} \mathrm{H}_{10} \mathrm{O}_{2}$ & 150.18 & 1-(2-hydroxy-5-methylphenyl) ethanone \\
\hline 8 & 21.626 & 1.33 & $\mathrm{C}_{11} \mathrm{H}_{29} \mathrm{O}_{6} \mathrm{PSi}_{3}$ & 372.57 & Acetic acid, [bis[(trimethylsilyl)oxy]- \\
\hline 9 & 22.977 & 1.06 & $\mathrm{C}_{9} \mathrm{H}_{17} \mathrm{NO}$ & 155.24 & 2-(tetrahydro-2-furanyl)Piperidine \\
\hline 10 & 24.028 & 2.97 & $\mathrm{C}_{10} \mathrm{H}_{13} \mathrm{NO}_{2}$ & 179.22 & 1-Phenylalanine, methyl ester \\
\hline 11 & 26.993 & 7.51 & $\mathrm{C}_{14} \mathrm{H}_{42} \mathrm{O}_{7} \mathrm{Si}_{7}$ & 519.07 & Tetradecamethyl cycloheptasiloxane \\
\hline 12 & 28.870 & 1.13 & $\mathrm{C}_{11} \mathrm{H}_{11} \mathrm{~N}$ & 157.21 & 3-Methyl-4-phenyl-1H-pyrrole \\
\hline 13 & 31.753 & 2.95 & $\mathrm{C}_{16} \mathrm{H}_{48} \mathrm{O}_{8} \mathrm{Si}_{8}$ & 593.20 & Hexadecamethyl cyclooctasiloxane \\
\hline 14 & 33.893 & 1.98 & $\mathrm{C}_{9} \mathrm{H}_{10} \mathrm{~N}_{2} \mathrm{O}_{2}$ & 178.19 & 5,6-Dimethoxybenzimidazole \\
\hline 15 & 35.907 & 2.79 & $\mathrm{C}_{18} \mathrm{H}_{54} \mathrm{O}_{9} \mathrm{Si}_{9}$ & 667.40 & Octadecamethyl cyclononasiloxane \\
\hline 16 & 36.939 & 6.29 & $\mathrm{C}_{17} \mathrm{H}_{34} \mathrm{O}_{2}$ & 270.50 & Methyl palmitate \\
\hline 17 & 37.295 & 11.05 & $\mathrm{C}_{16} \mathrm{H}_{32} \mathrm{O}_{2}$ & 256.42 & n-Hexadecanoic acid \\
\hline 18 & 37.489 & 2.27 & $\mathrm{C}_{18} \mathrm{H}_{23} \mathrm{~N}_{3}$ & 281.40 & $\begin{array}{c}\text { 3,6-Bis(N-dimethylamino)-9- } \\
\text { ethylcarbazole }\end{array}$ \\
\hline 19 & 38.203 & 2.19 & $\mathrm{C}_{19} \mathrm{H}_{34} \mathrm{O}_{2}$ & 294.5 & methyl ester 9,12-Octadecadienoic acid \\
\hline 20 & 38.240 & 8.92 & $\mathrm{C}_{19} \mathrm{H}_{32} \mathrm{O}_{2}$ & 292.5 & Methyl ester 9,12,15-Octadecatrienoic acid \\
\hline 21 & 38.321 & 9.18 & $\mathrm{C}_{20} \mathrm{H}_{40} \mathrm{O}$ & 296.5 & Phytol \\
\hline 22 & 38.497 & 20.37 & $\mathrm{C}_{18} \mathrm{H}_{32} \mathrm{O}$ & 264.4 & (Z,Z,Z) 9,12,15-Octadecatrien-1-ol \\
\hline 23 & 39.247 & 1.55 & $\mathrm{C}_{16} \mathrm{H}_{17} \mathrm{~N}_{3} \mathrm{O}_{2}$ & 283.32 & Amonafide \\
\hline
\end{tabular}

elevated compared to the model group. Groups pre-treated with the extracts showed dose-dependent elevation $(\mathrm{P}<0.05)$ of activities of both CAT and SOD with maximum elevation seen in the group given $400 \mathrm{mg} / \mathrm{kg}$ body wt. of the extract. The levels of these antioxidant enzymes in the group pre-treated with $400 \mathrm{mg} / \mathrm{kg}$ body wt. exhibited no significant difference compared to the normal group $(\mathrm{P}>0.05)$. However, MDA activities were significantly increased in the model group compared to the normal group $(\mathrm{P}$ $<0.05)$. The levels of MDA in groups administered with extract and aspirin at 400 and $30 \mathrm{mg} / \mathrm{kg}$ body wt. respectively revealed significantly lower MDA activities $(\mathrm{P}<0.05)$ compared to the model group but not significantly different results $(P>0.05)$ from the normal group (Table 5).

Effect of treatment on serum proinflammatory cytokines: interleukine-1 (IL-1 $\beta$ ), interleukine-6 (IL-6), and necrotic tissue factor (TNF- $\alpha$ )

Serum activities of pro-inflammatory cytokines (IL$1 \beta$, IL- 6 , and TNF- $\alpha$ ) in the model group were significantly $(\mathrm{P}<0.05)$ increased compared to the normal group (Table 6). Conversely, reduced serum levels of IL- $1 \beta$, IL- 6 , and TNF- $\alpha$ were exhibited in all the pretreatment groups compared to the model group with a 
Table 4: Data showing effects of cardiac trponin-I and $\mathrm{Na}^{+} / \mathrm{K}^{+}$ATPase in isoproterenol induced myocardial infarcted rats

\begin{tabular}{lcc}
\hline Treatment & $\begin{array}{c}\text { Troponil-I } \\
(\mathbf{n g} / \mathbf{m l})\end{array}$ & $\begin{array}{c}\text { Na+/K+ ATPase } \\
(\boldsymbol{\mu m o l} / \mathbf{P i} / \mathbf{m g} \text { Prot./hr })\end{array}$ \\
\hline Normal control & $9.06 \pm 0.59$ & $3.06 \times 10^{-4} \pm 3.31 \times 10^{-5}$ \\
ISO & $20.75 \pm 1.25^{a}$ & $1.40 \times 10^{-4} \pm 3.21 \times 10^{-5 a}$ \\
$\mathrm{C}(100)+\mathrm{ISO}$ & $17.11 \pm 1.60^{a}$ & $1.80 \times 10^{-4} \pm 3.62 \times 10^{-5 a}$ \\
$\mathrm{C}(200)+\mathrm{ISO}$ & $14.84 \pm 1.09^{a}$ & $2.05 \times 10^{-4} \pm 3.09 \times 10^{-5}$ \\
$\mathrm{C}(400)+\mathrm{ISO}$ & $10.77 \pm 2.14^{b}$ & $2.84 \times 10^{-4} \pm 2.93 \times 10^{-5 b}$ \\
ASP & $11.08 \pm 1.82^{b}$ & $2.75 \times 10^{-4} \pm 2.60 \times 10^{-5 b}$ \\
\hline
\end{tabular}

The data are expressed as mean \pm SD and analyzed using one-way analysis of variance (ANOVA) and later subjected to Dunnett's post hoc test for multiple comparisons. The expressed significant differences were considered at $\mathrm{p}<0.05,{ }^{a} \mathrm{p}<0.05$, when compared to normal control; ${ }^{b} \mathrm{p}<0.05$, when compared to ISO control $(\mathrm{n}=8)$.

Table 5: Effect of aqueous extract Musa paradisiaca peels on antioxidant enzymes and lipid peroxidation in isoproterenol induced myocardial infarcted rats

\begin{tabular}{lccc}
\hline Treatment & $\begin{array}{c}\text { SOD } \\
(\boldsymbol{\mu} / \mathrm{ml})\end{array}$ & $\begin{array}{c}\text { CAT } \\
(\mu \mathrm{mol} / \mathbf{m l} / \mathbf{m i n s})\end{array}$ & $\begin{array}{c}\text { MDA } \\
(\mathbf{n m o l} / \mathbf{m L})\end{array}$ \\
\hline Normal control & $1.15 \pm 0.22$ & $36.77 \pm 1.22$ & $11.24 \pm 2.54$ \\
ISO & $0.24 \pm 0.08^{a}$ & $20.89 \pm 2.17^{a}$ & $27.44 \pm 5.01^{a}$ \\
$\mathrm{C}(100)+\mathrm{ISO}$ & $0.35 \pm 0.11$ & $21.10 \pm 2.24$ & $25.22 \pm 5.54$ \\
$\mathrm{C}(200)+\mathrm{ISO}$ & $0.58 \pm 0.09$ & $26.82 \pm 1.50$ & $22.21 \pm 3.94^{b}$ \\
$\mathrm{C}(400)+\mathrm{ISO}$ & $0.92 \pm 0.17^{b}$ & $32.24 \pm 1.94^{b}$ & $12.85 \pm 1.38^{b}$ \\
ASP & $0.84 \pm 0.14^{b}$ & $31.72 \pm 1.56^{b}$ & $13.34 \pm 1.84^{b}$ \\
\hline
\end{tabular}

The data are expressed as mean \pm SD and analyzed using one-way analysis of variance (ANOVA) and later subjected to Dunnett's post hoc test for multiple comparisons. The expressed significant differences were considered at $\mathrm{p}<0.05 .{ }^{a} \mathrm{p}<0.05$, when compared to normal control; ${ }^{b} \mathrm{p}<0.05$, when compared to ISO control $(\mathrm{n}=8)$

Table 6: Effect of aqueous extract of Musa paradisiaca peels on serum pro-inflammatory cytokines in isoproterenol induced myocardial infarcted rats

\begin{tabular}{lccc}
\hline Treatment & IL- $\mathbf{\beta}(\mathbf{p g} / \mathbf{m l})$ & IL-6 $(\mathbf{p g} / \mathbf{m l})$ & TNF- $\boldsymbol{\alpha}(\mathbf{p g} / \mathbf{m l})$ \\
\hline Normal control & $111.40 \pm 1338$ & $6.63 \pm 1.96$ & $84.22 \pm 7.33$ \\
ISO & $218.30 \pm 18.87^{a}$ & $22.96 \pm 3.00^{a}$ & $162.80 \pm 13.84^{a}$ \\
C $(100)+$ ISO & $210.00 \pm 12.10$ & $21.76 \pm 3.22$ & $141.50 \pm 10.57$ \\
C $(200)+$ ISO & $187.60 \pm 23.26^{b}$ & $15.65 \pm 2.01$ & $122.60 \pm 4.39$ \\
C $(400)+$ ISO & $116.00 \pm 14.01^{b}$ & $10.46 \pm 2.19^{b}$ & $99.86 \pm 9.81^{b}$ \\
ASP & $117.50 \pm 14.53$ & $11.90 \pm 1.94^{b}$ & $101.90 \pm 11.02^{b}$
\end{tabular}

The data are expressed as mean \pm SD and analyzed using one-way analysis of variance (ANOVA) and later subjected to Dunnett's post hoc test for multiple comparisons. The expressed significant differences were considered at $\mathrm{p}<0.05 .{ }^{a} \mathrm{p}<0.05$, when compared to normal control; ${ }^{b} \mathrm{p}<0.05$, when compared to ISO control $(\mathrm{n}=8)$ 


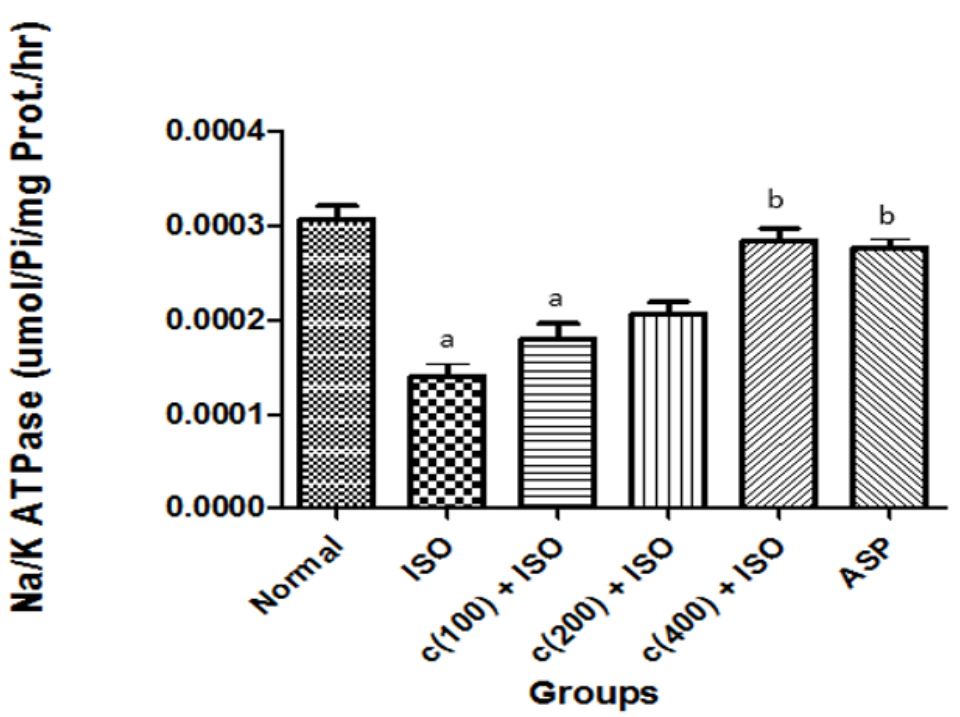

Figure 3: Effect of aqueous extract of Musa paradisiaca peels on cardiac $\mathrm{Na}^{+} / \mathrm{K}^{+}$ATPase activity in isoproterenol induced myocardial infarcted rats. The data are expressed as mean $\pm \mathrm{SD}$ and analyzed using one-way analysis of variance (ANOVA) and later subjected to Dunnett's post hoc test for multiple comparisons. The expressed significant differences were considered at $\mathrm{p}<0.05 .{ }^{a} \mathrm{p}<0.05$, when compared to normal control; ${ }^{b} \mathrm{p}<$ 0.05 , when compared to ISO control $(n=8)$. https://doi.org/10.6084/m9.figshare.16903810.v1

marked reduction $(\mathrm{P}<0.05)$ observed in groups given the extract and aspirin at 400 and $30 \mathrm{mg} / \mathrm{kg}$ body wt. respectively.

\section{Effect of treatment on serum electrolytes levels}

The activities of the serum electrolytes, $\mathrm{Cl}^{-}$and $\mathrm{Ca}^{2+}$, in the normal model and pre-treated groups, revealed no significant difference $(\mathrm{P}>0.05)$ except for reduced levels of $\mathrm{Cl}^{-}$in groups pre-treated with extracts at 100 and $200 \mathrm{mg} / \mathrm{kg}$ body wt. compared to the normal group $(\mathrm{P}<0.05)$ (Table 7$)$. In the model group, activities of $\mathrm{Na}^{+}$and $\mathrm{K}^{+}$were significantly lower compared to the normal group $(\mathrm{P}<0.05)$. Also, activities of groups pre-treated with extracts at $400 \mathrm{mg} / \mathrm{kg}$ body wt. as well as aspirin at $30 \mathrm{mg} / \mathrm{kg}$ body wt. exhibited marked elevation of $\mathrm{Na}^{+}$and $\mathrm{K}^{+}$activities $(\mathrm{P}<$ $0.05)$ compared to the model group and were not significantly different $(\mathrm{P}>0.05)$ from the normal group (Table 7).

Effect of treatment on electrocardiographic changes (electrical tracing on ECG paper) in isoproterenol-induced Myocardial Infarction

Figure 4A-F depict electrical tracings of cardiomyocytes (P, QRS, and T wave) in different groups on
ECG paper. Normal R-R and PR intervals were observed in the normal group (Figure 4A), while the model group showed a taller and wider $\mathrm{T}$ wave evidenced by ST elevation, prolonged PR interval, narrow QRS complex, and irregular R-R interval (Figure 4B). Animals pre-treated with the extract's $100 \mathrm{mg} / \mathrm{kg}$ body weight revealed irregular an R-R interval, narrow QRS complex, and minimized ST elevation (Figure 4C). Consequently, pre-treatment with extract (Figure 4D) and aspirin (Figure 4F) at 200 and $30 \mathrm{mg} / \mathrm{kg}$ body wt. respectively before induction of myocardial infarction revealed atrial fibrillation and an irregular R-R interval. However, pretreatment with $400 \mathrm{mg} / \mathrm{kg}$ body wt. extract showed a normal QRS complex and a reduced ST segment accompanied by repeated loops of $\mathrm{T}$ and $\mathrm{P}$ waves (Figure $4 \mathrm{E}$ ).

\section{Effect of treatment on histopathology of the myocardium by staining with Hema- toxylin and Eosin (H\&E x 100)}

Following staining of the heart with H\&E, histological assessment of the cardiomyocytes was carried out (Figure 5). Histological findings of cardiomyocytes from the normal group showed regular heart structure characterized by the absence of inflammatory cells and no observable cellular damage (Figure 5A). 
Table 7: Effect of aqueous extract of Musa paradisiaca peels on serum electrolytes levels in isoproterenol-induced myocardial infarction in rats

\begin{tabular}{lcccc}
\hline Treatment & $\mathbf{N a}^{+}(\mathbf{m m o l} / \mathbf{l})$ & $\mathbf{K}^{+}(\mathbf{m m o l} / \mathbf{l})$ & $\mathbf{C l}^{-}(\mathbf{m m o l} / \mathbf{l})$ & $\mathbf{C a}^{2+}(\mathbf{m m o l} / \mathbf{l})$ \\
\hline Normal control & $94.90 \pm 2.22$ & $6.21 \pm 0.36$ & $42.13 \pm 3.87^{a}$ & $1.92 \pm 0.11^{a}$ \\
ISO & $80.21 \pm 8.21^{b}$ & $3.30 \pm 0.35^{b}$ & $42.83 \pm 071^{a}$ & $1.73 \pm 0.07^{a}$ \\
$\mathrm{C}(100)+\mathrm{ISO}$ & $89.30 \pm 3.32^{c}$ & $4.00 \pm 1.00^{b}$ & $39.01 \pm 2.73^{b}$ & $1.72 \pm 0.09^{a}$ \\
$\mathrm{C}(200)+\mathrm{ISO}$ & $89.30 \pm 2.85^{c}$ & $4.47 \pm 1.01^{c}$ & $37.72 \pm 4.33^{b}$ & $1.61 \pm 0.12^{a}$ \\
$\mathrm{C}(400)+\mathrm{ISO}$ & $92.79 \pm 1.63^{c}$ & $5.33 \pm 0.60^{c}$ & $42.74 \pm 3.27^{a}$ & $1.73 \pm 0.09^{a}$ \\
$\mathrm{ASP}$ & $90.25 \pm 3.62^{c}$ & $4.79 \pm 0.88^{c}$ & $42.45 \pm 2.37^{a}$ & $1.81 \pm 0.25^{a}$ \\
\hline
\end{tabular}

The data are expressed as mean \pm SD and analyzed using one-way analysis of variance (ANOVA) and later subjected to Dunnett's post hoc test for multiple comparisons. The expressed significant differences were considered at $\mathrm{p}<0.05 .{ }^{a} \mathrm{p}>0.05$, when groups are not significantly different from one another, ${ }^{b} \mathrm{p}<0.05$, when compared to normal group, ${ }^{c} \mathrm{p}<0.05$, when compared to ISO control group $(\mathrm{n}=8)$.
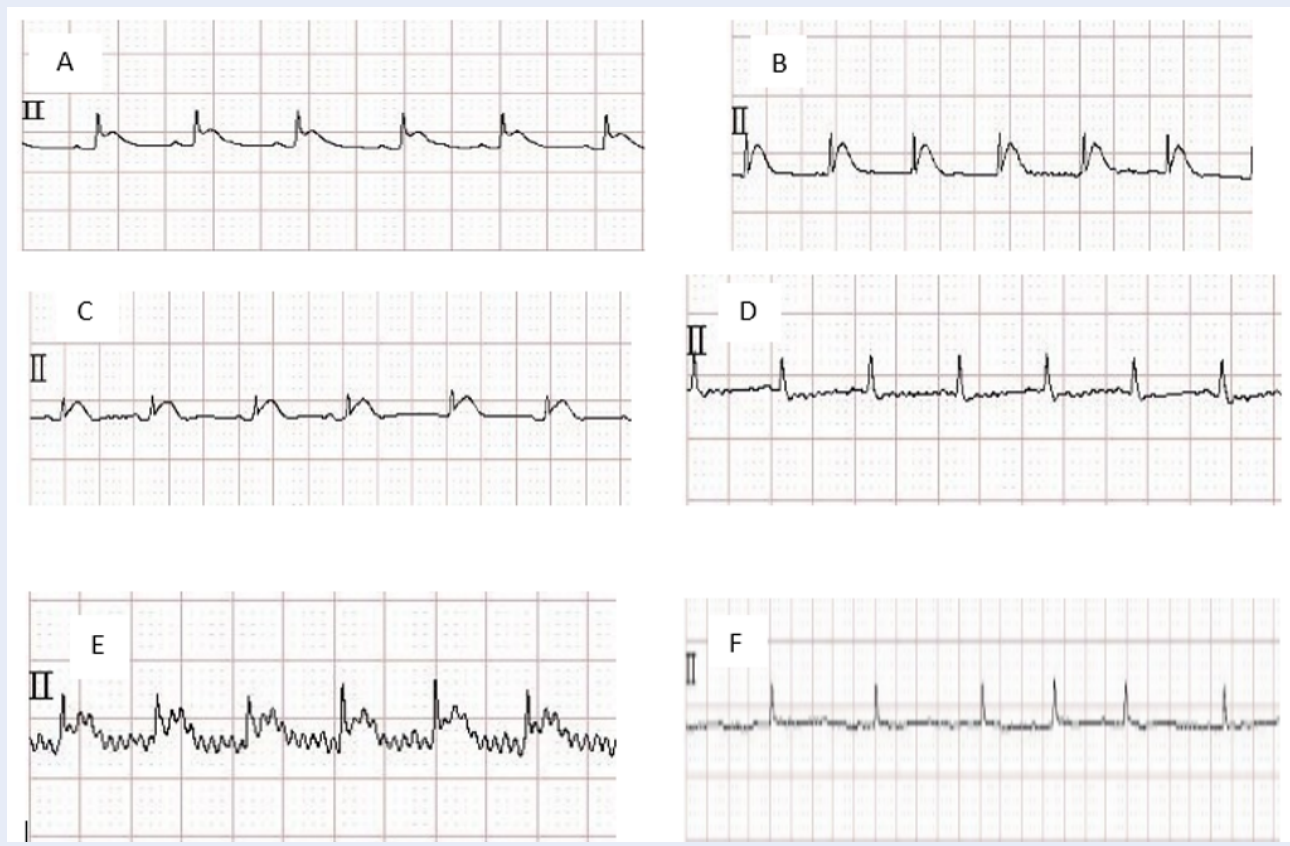

Figure 4: Electrocardiographic changes on ECG paper. (A) Normal control group showing regular R-R and normal PR interval.(B) Model group showing ST elevation, irregular R-R interval, 'S' is located on the isoelectric baseline and narrow QRS. (C) Group pre-treated with $100 \mathrm{mg} / \mathrm{kg}$ body wt. extract showing minimized ST elevation, narrow and shorter QRS and irregular R-R interval. (D) Group pre-treated with $200 \mathrm{mg} / \mathrm{kg}$ body wt. extract showinglocation of ' $S$ ' below the isoelectric baseline, atrial fibrillation and irregular R-R interval. (E) Group pre-treated with 30 $\mathrm{mg} / \mathrm{kg}$ body wt. of aspirin showing atrial fibrillation and irregular R-R interval. https://doi.org/10.6084/m9.figsha re.16903870.v1 

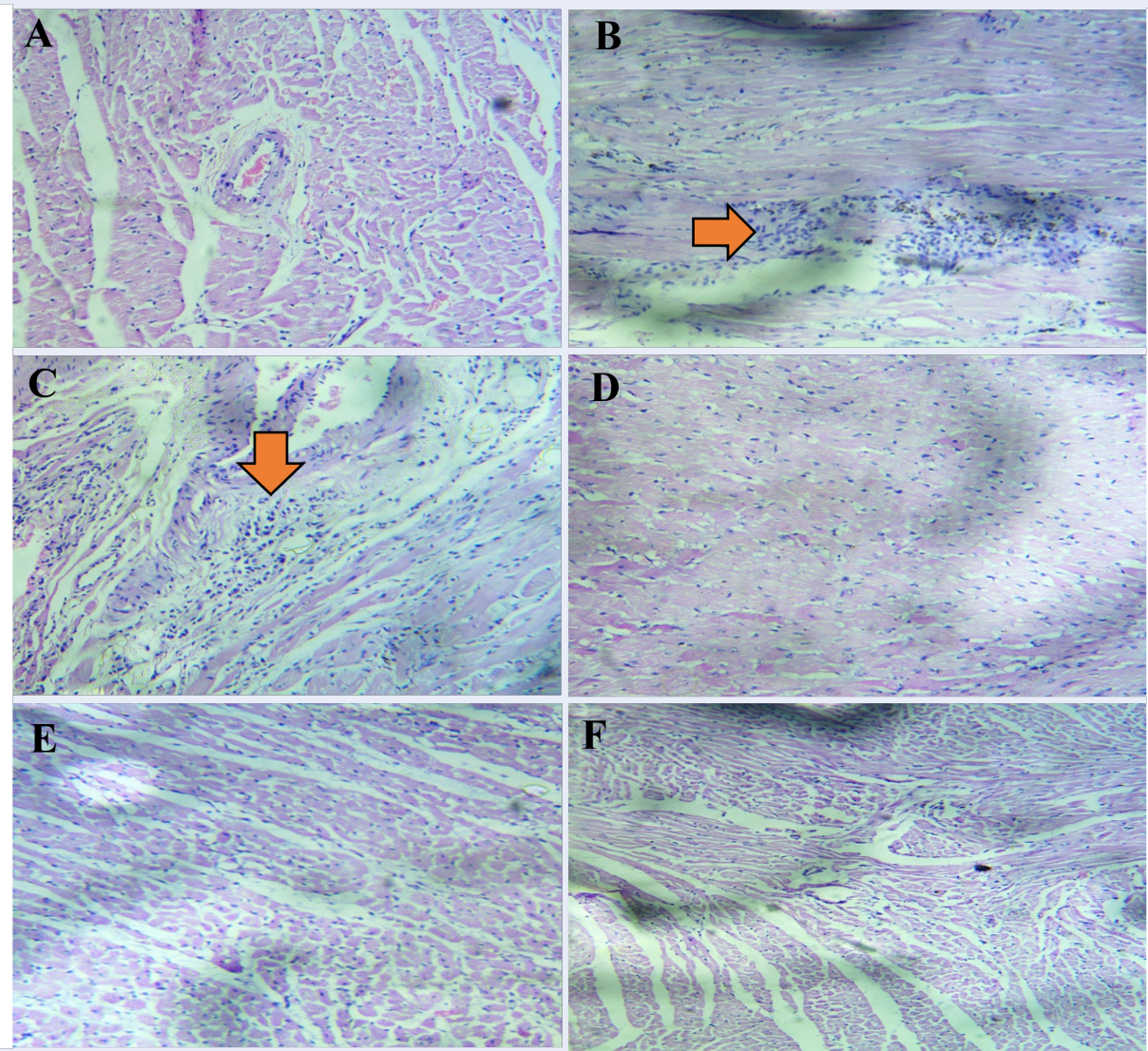

Figure 5: Effect of aqueous extract of Musa paradisiaca peels treatment on cardiaomyocytes stained with Haematoxylin and Eosin. (A) Control group showing no observable cellular damage. (B) Model group showing ongoing cellular degenerative changes with heavy neutrophil infiltration. (C) Group pretreated with extract at 100 $\mathrm{mg} / \mathrm{kg}$ body wt. showing heavy neutrophil infiltration with necrotic areas. (D) Group pre-treated with extract at $200 \mathrm{mg} / \mathrm{kg}$ body wt. showing few inflammatory cells. (E) Group pre-treated with extract at $400 \mathrm{mg} / \mathrm{kg}$ body wt. showing less infiltration of inflammatory cells and few necrotic areas (F) Pre-treatment with aspirin showing less cellular damage and few inflammatory cells (H\&E x 100). https://doi.org/10.6084/m9.figshare.16903876.v1

The model group revealed necrotic wavy cardiac muscle cells with degenerative cellular changes and heavy neutrophil infiltration (arrow) (Figure 5B). Mild necrotic areas with heavy neutrophil infiltration were evidenced (arrow) in the hearts of the group pre-treated with extract at $100 \mathrm{mg} / \mathrm{kg}$ body weight (Figure 5C). The group pre-treated with extract at $200 \mathrm{mg} / \mathrm{kg}$ body weight showed mild inflammation and proliferation of fibroblast, which progressively replaces necrotic cardiomyocyte (Figure 5D). Groups pre-treated with extract and aspirin at 400 and 30 $\mathrm{mg} / \mathrm{kg}$ body weight respectively exhibited typically normal myocardium with the reduced consequence of myocardial infarction evidenced by less infiltration of inflammatory cells and few necrotic areas induced by subcutaneous injection of isoproterenol (Figure $5 \mathbf{~ E}$ \& F).

\section{DISCUSSION}

In this study, we investigated the effect of MPPE on the restoration of rats' hearts in an ISO-induced model of MI using ASP as the reference drug. Manifestation of MI involves biochemical, electrocardiograph, hemodynamic, and histopathological alteration of the cardiomyocytes due to the reduction of endogenous antioxidants, escape of cardiac injury marker enzymes, and lipid peroxidation ${ }^{24}$. A reported protective effect of ASP in the hearts of myocardial infarcted subjects is attributed to its antithrombotic activity ${ }^{25}$. MPPE was previously reported to possess secondary metabolites responsible for their wide range of biological activities, including cardiovascular and antioxidant effects ${ }^{\mathbf{2 6}}$.

The findings from the present study reveal that Musa paradisiaca peel extract (MPPE) showed po- 
tential cardioprotective effects against ISO-induced MI most likely by ameliorating impaired cardiomyocytes $\mathrm{Na}^{+} / \mathrm{K}^{+}$ATPase activities and cTn-I leakages, supporting endogenous antioxidant defense system, hindering lipid peroxidation, restoring electrocardiograph ST elevation, promoting anti-inflammatory effects, and the histological preservation of cardiomyocytes evidenced by reduced myonecrosis with minimal inflammatory cells.

During the acute toxicity study, the aqueous extract of $M P P$ was found to save even at the $5000 \mathrm{mg} / \mathrm{kg}$ dose. Consequently, in this study, geometrical progression doses of 100,200 , and $400 \mathrm{mg} / \mathrm{kg}$ were chosen to evaluate the cardioprotective effect of the extract.

In this study, the presence of secondary metabolites such as flavonoids, phenolics, tannins, steroids, alkaloids, and glycosides were established following a phytochemical screening of the aqueous MPPE. This aligns with findings from a previous study that documented their possession of multiple pharmacological and biological effects ${ }^{14}$. The presence of these secondary metabolites in the MPPE suggests explorable antioxidant and anti-inflammatory potentials present in the peels of Musa paradisiaca.

The GC-MS analysis of Musa paradisiaca extract revealed 23 bioactive compounds, many of which had been documented to exert a cardioprotective effect through their antioxidant and anti-inflammatory activities $^{27,28}$. As showed in our study, $(\mathrm{Z}, \mathrm{Z}, \mathrm{Z})$ 9,12,15-Octadecatrien-1-ol and n-Hexadecanoic acid possessing maximum percentage peak area is documented to have antioxidant properties ${ }^{28,29}$. Further, Methyl ester 9,12,15-Octadecatrienoic acid, and Phytol with a moderate percentage peak area have antioxidant and anti-inflammatory properties as reported in previous studies ${ }^{27,29,30}$. Methyl palmitate and methyl ester 9,12-Octadecadienoic acid were reported as antioxidant and anti-inflammatory compounds, respectively ${ }^{28,31}$.

Injection of isoproterenol (ISO) is regarded as the universal and convenient means by which MI is induced in vivo to evaluate anticipated cardioprotective agents as it causes similar pathophysiological and molecular changes in the heart of rats as compared to what is obtainable in humans ${ }^{1}$. Consequent upon isoproterenol administration, oxidative damage of cardiomyocytes results from the excessive generation of free radicals produced from autoxidation of catecholamine, causing a reduction in activities of endogenous antioxidant systems leading to inequality of pro-oxidant/antioxidant levels in the cardiomyocytes 4 .
Catalase (CAT) and superoxide dismutase (SOD) are endogenous antioxidant enzymes that serve as a firstline defense against oxidative injury by scavenging free radicals and opposing the formation of reactive oxygen species (ROS). The present study revealed a significant reduction in the activities of antioxidant enzymes (CAT and SOD) in animal models of ISOinduced myocardial infarction. This suggests oxidative damage to the cardiomyocytes due to the accumulation of free radicals ${ }^{32}$. Interestingly, serum levels of CAT and SOD were remarkably elevated in rats pre-treated with Musa paradisiaca peel extract more than those of ASP, suggesting the presence of its antioxidant and free radical scavenging potentials as reported in a previous study ${ }^{9}$. Hence, the present study upholds the fact that Musa paradisiaca peel extract displays a cardioprotective effect due to its antioxidant properties. Increased lipid peroxidation, evidenced by elevation of malondialdehyde (MDA) in ISO-induced MI rats, indicates the susceptibility of hearts to oxidative injury due to myocardial membrane damage following increased production of free radicals ${ }^{33}$. Pre-treatment with MPPE reduced the elevation of MDA relative to ASP in ISO-induced MI rats, thus revealing its cardioprotective effect possibly by scavenging accumulated free radicals consequently produced to ISO administration ${ }^{8}$.

Cardiac troponin-I (cTn-I) is a contractile protein reported to be a specific marker for myocardial cell injury found in the serum consequent to cardiomyocyte damage ${ }^{34}$. In this study, an increased serum cTn-I was attributed to damage to the sarcolemma following injection of ISO in ISO-induced MI rats, causing cTnI leaks into the serum ${ }^{5}$. Conversely, ISO-induced MI rats pre-treated with Musa paradisiaca peel extract had lowered serum levels of cTn-I, suggesting a cardioprotective effect of the extract by minimizing leakage of cTn-I as a result of its (MPPE) antioxidant effect.

Following MI or ischemic heart disease, inflammatory responses are essentially mediated in the heart by pro-inflammatory cytokines (IL- $1 \beta$, IL-6, and TNF$\alpha$ ) that are implicated in the healing process post$\mathrm{MI}^{35}$. A previous study reported elevation of proinflammatory cytokines in both ISO-induced animal and human $\mathrm{MI}^{36}$. The present investigation revealed increased levels of IL- $1 \beta$, IL- 6 , and TNF- $\alpha$ in ISOinduced MI rats reflecting ongoing inflammatory processes, which aligns with findings from the previous study. However, pre-treatment with MPPE protected the cardiac membrane from the deleterious effect of ISO-induced MI by assuming an antioxidant effect. This is reflected by reduction of the expression of 
TNF- $\alpha$, IL- $1 \beta$, and IL- 6 and a subsequent minimization of inflammation in the heart of ISO-induced MI rats. This effect followed a dose-dependent manner with the highest anti-inflammatory effect expressed in the group pre-treated with the extract's $400 \mathrm{mg} / \mathrm{kg}$ body wt.

The development of many diseases, including MI, are reported to occur due to the inability of the cell membrane to physiologically maintain the transmembrane ionic concentration ${ }^{\mathbf{5}}$. The ubiquitous transmembrane protein $\mathrm{Na}^{+} / \mathrm{K}^{+}$ATPase predominantly regulates ionic $\left(\mathrm{Na}^{+}\right.$and $\left.\mathrm{K}^{+}\right)$balance across the cardiomyocytes, thereby contributing to cardiac contractility and membrane potential ${ }^{5,37}$. Administration of ISO inhibited activities of $\mathrm{Na} / \mathrm{K}$-ATPase, thereby distorting movement of electrolytes across the membrane, indicating myocardial injury due to susceptibility of the enzymes' active site to free radical attack $^{38}$. In a dose-dependent manner, pre-treatment with Musa paradisiaca peel extract promotes restoration of $\mathrm{Na} / \mathrm{K}$-ATPase activities in the cardiomyocytes, which indicates the preservative potential of the extract on cardiomyocytes membrane by rendering it less leaky, consequent to the inhibition of lipid peroxidation and reduction in membrane disruption.

Electrocardiogram remains an important tool for clinical diagnosis of MI by recording the heart's electrical activity, thus forming the basis for instant therapeutic interventions when correctly interpreted ${ }^{1,17}$. In the present study, a manifestation of ST segments elevation, prolonged PR interval, irregular R-R, and a narrow QRS complex observed in the ISO-induced group suggests ongoing myocardial necrosis and inflammation in the ventricles atrioventricular block caused by ISO injection ${ }^{39}$. Pre-treatment with Musa paradisiaca peel extract in ISO-induced MI rats revealed a minimization of the atrial fibrillation effect of ISO administration in a dose-dependent manner relative to ASP, suggestive of its cell membrane protective effects. However, delay of the expected ECG pattern (near to normal) as observed in group pretreated with $400 \mathrm{mg} / \mathrm{kg}$ body wt. of Musa paradisiaca peel extract may be due to physiological adaptation to arrhythmogenic changes or ECG, or to ISO-induced $\mathrm{MI}$ in the pre-treatment group hearts, which may require a longer time for a complete reversal ${ }^{\mathbf{1}}$.

The balance of electrolytes in the body is essential for normal bodily cells and organ function, including the heart. Regulation of the heart's electrical activity depends on a normal level of calcium, potassium, and sodium, whereas optimum contraction of the heart requires calcium, magnesium, and phosphorus ${ }^{40}$. The reduction in serum activities of both
$\mathrm{Na}^{+}$and $\mathrm{K}^{+}$following administration of ISO can be attributed to ongoing oxidative damage as a consequence of a free radical attack on the $\mathrm{Na}^{+} / \mathrm{K}^{+}$pump causing its impairment ${ }^{41}$. However, pre-treatment with Musa paradisiaca peel extract resulted in the elevation of the electrolytes, $\mathrm{Na}^{+}$and $\mathrm{K}^{+}$, suggesting responsiveness of electrical conductivity of the heart. Histopathological examination of myocardial tissue in normal control rats revealed no observable cellular damage evidenced with intact myocardial structure. The group administered ISO alone showed marked necrosis and infiltration of inflammatory cells ${ }^{4}$. However, pre-treatment with Musa paradisiaca peel extract resulted in a reduced level of myonecrosis and a lowered level of inflammatory cells in a dose-dependent manner. This further buttressed the cardio-protective nature of Musa paradisiaca peel extract in ISO-induced myocardial injury. This cardio-protective effect may be partly due to its antioxidant effect.

Therefore, we suggest further work on the isolation and identification of the antioxidant and antiinflammatory effects of bioactive compounds as revealed by GC-MS analysis of Musa paradisiaca extract. This would enable the discovery of novel drugs with adequate knowledge of their pharmacological activities. Also, echocardiography, in addition to electrocardiography, should be conducted to further give credence to the therapeutic claim of the reversal effect of Musa paradisiaca extract.

\section{CONCLUSION}

This study demonstrated a positive prognosis of Musa paradisiaca peel extract (MPPE) by offering protection to the myocardium in ISO-induced myocardial infarction (MI) rats. The effect of MPPE in offering protection to the myocardium in ISO-induced $\mathrm{MI}$ rats may be due to its antioxidant effect. This investigation reaffirmed the antioxidant effect of MPPE. It demonstrated the anti-inflammatory effect responsible for minimizing oxidative stress, hindering elevation of pro-inflammatory cytokines (IL- $1 \beta$, IL-6, and TNF- $\alpha$ ), and thereby promoting restoration of histoarchitecture of the myocardium in ISO-induced MI rats.

\section{ABBREVIATIONS}

CAT: Catalase

cTn-I: Cardiac troponin-I

ECG: Electrocardiograph

GC-MS: Gas Chromatography — Mass Spectrometry

IL-1 $\beta$ : Interleukine- $1 \beta$

IL-6: Interleukine- $6 \beta$ 
ISO: Isoproterenol

$\mathbf{L D}_{50}$ : Median lethal dose that could kill $50 \%$ of the population

MDA: Malondialdehyde

MI: Myocardial infarction

MPPE: Musa paradisiaca peel extract

ROS: Reactive oxygen species

SOD: Superoxide dismutase

TNF- $\alpha$ : Tissue nectrosis factor alpha

\section{ACKNOWLEDGMENTS}

Our sincerer appreciations go to the Vice Chancellor, University of Ilorin, Prof. Abdulkareem Agei by partly funding this research as well as Prof. S.F. Ambali of Department of Veterinary Pharmacology and Toxicology, Faculty of Veterinary Medicine, University of Ilorin, Nigeria for his support and encouragement during the course of this work.

\section{AUTHOR'S CONTRIBUTIONS}

(1) Conception and Study Design: Suleiman K.Y., Ajani E.O., Biobaku, K.T; (2)Toxicity determination: Akorede G.J., Biobaku, K.T., Suleiman K.Y.; (3) Extract dosage formulation: Aremu A., Suleiman K.Y.; (4) Biochemical assays analysis: Suleiman K.Y., Ajani E.O., Biobaku, K.T.; (5) ECG determination: Azeez M.O., Suleiman K.Y.; (6) Histopathology examination: Okediran B.S., Suleiman K.Y., Ahmed A.O.; (7) Acquisition of data: Suleiman K.Y., Akorede G.J.; (8) Data analysis and interpretation: Suleiman K.Y., Ajani E.O., Biobaku, K.T.; (9) Drafting of the article: Suleiman K.Y.; (10) Revision and proofreading: Suleiman K.Y., Ajani E.O., Biobaku, K.T., Ahmed A.O.; (11) Final approval: Suleiman K.Y., Ajani E.O., Biobaku, K.T., Okediran B.S., Azeez, M.O., Akorede G.J., Aremu A., Ahmed A.O.

\section{FUNDING}

The first Author declared that that research was partly funded by Vice Chancellor, University of Ilorin, Nigeria, Prof. Abdulkareem Agei through staff development award.

\section{AVAILABILITY OF DATA AND MATERIALS}

Data and materials used and/or analyzed during the current study are available from the corresponding author on reasonable request.

\section{ETHICS APPROVAL AND CONSENT TO PARTICIPATE}

Not applicable.

\section{CONSENT FOR PUBLICATION}

Not applicable.

\section{COMPETING INTERESTS}

The authors declare that they have no competing interests.

\section{REFERENCES}

1. Shanmugam G, Challa AK, Litovsky SH, Devarajan A, Wang D, Jones DP. Enhanced Keap1-Nrf2 signaling protects the myocardium from isoproterenol-induced pathological remodeling in mice. Redox Biol. 2019;27(May):101212. PMID: 31155513. Available from: 10.1016/j.redox.2019.101212.

2. Prince PSM, Dhanasekar K, Rajakumar S, Rajakumar S. Vanillic acid prevents altered ion pumps, ions, inhibits Fas-receptor and caspase mediated apoptosis-signaling pathway and cardiomyocyte death in myocardial infarcted rats. Chem Biol Interact. 2015;232(March):68-76. PMID: 25794854. Available from: 10.1016/j.cbi.2015.03.009.

3. Lin JK, Moran AE, Bibbins-Domingo $K$, Falase $B$, Tobias AP, Mandke CN. Cost-effectiveness of a fixed-dose combination pill for secondary prevention of cardiovascular disease in China, India, Mexico, Nigeria, and South Africa: a modelling study. Lancet Glob Health. 2019;7(10):e1346-58. PMID: 31477544. Available from: 10.1016/S2214-109X(19)30339-0.

4. Hemalatha KL, Prince PSM. Anti-inflammatory and antithrombotic effects of zingerone in a rat model of myocardial infarction. Eur J Pharmacol. 2016;791:595-602. PMID: 27568839. Available from: 10.1016/j.ejphar.2016.08.023.

5. Bhaskaran SK, Kannappan P. Protective effect of Azolla microphylla on biochemical, histopathological and molecular changes induced by isoproterenol in rats. Biomed Pharmacother. 2017;89:473-81. PMID: 28249249. Available from: 10.1016/j.biopha.2017.01.177.

6. Bandyopadhyay D, Chattopadhyay A, Ghosh G, Datta AG. Oxidative stress-induced ischemic heart disease: protection by antioxidants. Curr Med Chem. 2004;11(3):369-87. PMID: 14965238. Available from: 10.2174/0929867043456016.

7. Khalil MI, Tanvir EM, Afroz R, Sulaiman SA, Gan SH. Cardioprotective effects of tualang honey: amelioration of cholesterol and cardiac enzymes levels. BioMed Res Int. 2015;2015:286051. PMID: 26064893. Available from: 10.1155/ 2015/286051.

8. Pereira A, Maraschin M. Banana (Musa spp) from peel to pulp: ethnopharmacology, source of bioactive compounds and its relevance for human health. J Ethnopharmacol. 2015;160:149-63. PMID: 25449450. Available from: 10.1016/j. jep.2014.11.008.

9. Vijayakumar S, Presannakumar G, Vijayalakshmi NR. Antioxidant activity of banana flavonoids. Fitoterapia. 2008;79(4):279-82. PMID: 18329185. Available from: $10.1016 /$ j.fitote.2008.01.007.

10. Mosa ZM, Khalil AF. The effect of banana peels supplemented diet on acute liver failure rats. Ann Agric Sci. 2015;60(2):373-9. Available from: 10.1016/j.aoas.2015.11.003.

11. Mohamed AR, El-Hadidy WF, Mannaa HF. Assessment of the prophylactic role of aspirin and/or clopidogrel on experimentally induced acute myocardial infarction in hypercholesterolemic rats. Drugs R D. 2014;14(4):233-9. PMID: 25231707. Available from: 10.1007/s40268-014-0059-3.

12. Doutremepuich C, Aguejouf O, Desplat V, Eizayaga FX. Paradoxical effect of aspirin. Thrombosis. 2012;2012:676237. PMID: 22292117. Available from: 10.1155/2012/676237.

13. Ajani EO, Ibrahim LB. Toxicological evaluations of combined administration of ethanolic stem bark extract of Enantia chlorantha and lisinopril in experimental type 2 diabetes. Clin Phytoscience [Internet]. 2020;29(6):1-9. Available from: 10.1186/ s40816-020-00174-z. 
14. Asuquo EG, Udobi CE. Antibacterial and toxicity studies of the ethanol extract of Musa paradisiaca leaf. Cogent Biol. 2016;47(1):1-10. Available from: 10.1080/23312025.2016. 1219248.

15. Banakar P, Jayaraj M. Pharmacognosy, Phytochemistry and GC-MS Analysis of Ethanolic Stem Extract of Waltheria indica L. - A Potent Medicinal Plant. J Biol Act Prod from Nat. 2017;1866(November):369-78. Available from: 10.1080/ 22311866.2017.1400923.

16. Lorke $D, A g B$. A new approach to practical acute toxicity testing. Arch Toxicol. 1983;54(4):275-87. PMID: 6667118. Available from: 10.1007/BF01234480.

17. Panda S, Kar A, Biswas S. Preventive effect of Agnucastoside $C$ against Isoproterenol-induced myocardial injury. Sci Rep. 2017;7(1):16146. PMID: 29170391. Available from: 10.1038/ s41598-017-16075-0.

18. Azeez OM, Basiru A, Akorede GJ, Adah SA. Electrocardiographic parameters in West African Dwarf and Red Sokoto (Maradi) goats. Sokoto J Vet Sci. 2018;16(2):41-6. Available from: 10.4314/sokjvs.v16i2.6.

19. Jayachandran KS, Vasanthi HR, Rajamanickam GV. Antilipoperoxidative and membrane stabilizing effect of diosgenin, in experimentally induced myocardial infarction. Mol Cell Biochem. 2009;327(1-2):203-10. PMID: 19234676. Available from: 10.1007/s11010-009-0058-9.

20. Ding M, Clayton C, Soldati D, Biologie M, Feld IN. Toxoplasma gondii catalase: are there peroxisomes in toxoplasma? J Cell Sci. 2000;113(Pt 13):2409-19. PMID: 10852820. Available from: $10.1242 /$ jcs.113.13.2409.

21. Buege JA, Aust SD. Microsomal lipid peroxidation. Methods in Enzymology. 1975;52(1978):302-310. Available from: 10. 1016/S0076-6879(78)52032-6.

22. Young DS. Effects of Drugs on Clinical Laboratory Test. AACC Press Washington; 1995.

23. Goyal SN, Sharma C, Mahajan UB, Patil CR, Agrawal YO, Kumari S. Protective Effects of Cardamom in Isoproterenol-Induced Myocardial Infarction in Rats. Int J Mol Sci. 2015;16(11):2745769. PMID: 26593900 . Available from: 10.3390/ijms 161126040.

24. Zhu P, Liu J, Shi J, Zhou O, Liu J, Zhang X. Melatonin protects ADSCs from ROS and enhances their therapeutic potency in a rat model of myocardial infarction. J Cell Mol Med. 2015;19(9):2232-43. PMID: 26081690. Available from: $10.1111 / \mathrm{jcmm} .12610$

25. Altman R, Luciardi HL, Muntaner J, Herrera RN. The antithrombotic profile of aspirin. Aspirin resistance, or simply failure? Thromb J. 2004;2(1):1-8. PMID: 14723795. Available from: 10.1186/1477-9560-2-1.

26. Ighodaro OM. Evaluation study on Nigerian species of Musa paradisiaca peels. Researcher. 2012;4(8):17-20.

27. Kumar PP, Kumaravel S, Lalitha C. Screening of antioxidant activity, total phenolics and GC-MS study of Vitex negundo. Afr J Biochem Res. 2010;4(7):191-5.

28. Nishanthini A, Mohan VR, Jeeva S. Phytochemical, ft-ir, and gcms analysis of stem and leaf of tiliacora acuminata (lan.) Hook $\mathrm{f} \&$ thomas (menispermaceae). International Journal of Pharmaceutical Sciences and Research. 2014;5(9):3977-86.

29. Starlin T, Prabha PS, Thayakumar BK, Gopalakrishnan VK. Screening and GC-MS profiling of ethanolic extract of Tylophora pauciflora. Bioinformation. 2019;15(6):425-9. PMID: 31312080. Available from: 10.6026/97320630015425.

30. Banjare J, Salunke M, Indapurkar K, Ghate U, Bhalerao S. Estimation of serum malondialdehyde as a marker of lipid peroxidation in medical students undergoing examination-induced psychological stress. J Sci Soc. 2017:44(3):137.

31. Rajeswari G, Murugan M, Mohan VR. GC-MS analysis of bioactive components of Hugonia mystax L. (Linaceae). J Pharm Biol Chem Sci [Internet]. 2013;29(4):818-24.

32. Zhang W, Li Y, Ge Z. Cardiaprotective effect of crocetin by attenuating apoptosis in isoproterenol induced myocardial infarction rat model. Biomed Pharmacother. 2017:93:376-82. PMID: 28651239. Available from: 10.1016/j.biopha.2017.06. PMID: 2 .

33. Wong ZW, Thanikachalam PV, Ramamurthy S. Molecular understanding of the protective role of natural products on isoproterenol-induced myocardial infarction: A review. Biomed Pharmacother. 2017;94:1145-66. PMID: 28826162 Available from: 10.1016/j.biopha.2017.08.009.

34. Wells SM, Sleeper M. Cardiac troponins. J Vet Emerg Crit Care (San Antonio). 2008;18(3):235-45. Available from: 10.1111/j. 1476-4431.2008.00307.x.

35. Yuan Y, Pan S, Yang SL, Liu YL, Xu QM. Antioxidant and cardioprotective effects of Ilex cornuta on myocardial ischemia injury. Chin J Nat Med. 2017;15(2):94-104. PMID: 28284430. Available from: 10.1016/S1875-5364(17)30025-0.

36. Shukla SK, Sharma SB, Singh UR. $\beta$-Adrenoreceptor Agonist Isoproterenol Alters Oxidative Status, Inflammatory Signaling, Injury Markers and Apoptotic Cell Death in Myocardium of Rats. Indian J Clin Biochem. 2015;30(1):27-34. PMID: 25646038. Available from: 10.1007/s12291-013-0401-5.

37. Kaplan JH. Biochemistry of Na,K-ATPase. Annu Rev Biochem. 2002;71(1):511-35. PMID: 12045105. Available from: 10.1146 annurev.biochem.71.102201.141218.

38. Fuller W, Parmar V, Eaton P, Bell JR, Shattock MJ. Cardiac ischemia causes inhibition of the $\mathrm{Na} / \mathrm{K}$ ATPase by a labile cytosolic compound whose production is linked to oxidant stress. Cardiovasc Res. 2003;57(4):1044-51. PMID: 12650882. Available from: 10.1016/S0008-6363(02)00810-6.

39. Ziaee M, Khorrami A, Ebrahimi M, Nourafcan H, Amiraslanzadeh M, Rameshrad M. Cardioprotective Effects of Essential Oil of Lavandula angustifolia on Isoproterenol-induced Acute Myocardial Infarction in Rat. Iran J Pharm Res. 2015;14(1):279_ 89. PMID: 25561934

40. Alizadehasl A, Sepasi F, Azarfarin R, Ghaffari S. Hypokalemia, Arrhythmias and Early Outcomes in Acute Myocardial Infarction. Res J Biol Sci. 2008;9(3):1130-2.

41. Hariprasad S, Basavaraj M. Electrolyte dysfunction in myocardial infarction patients. Int J Adv Med. 2018;5(5):1172-6. Available from: 10.18203/2349-3933.ijam20183872. 
Ready to submit your manuscript? Choose Biomedpress and benefit from:

- Fast, convenient online submission

- Through peer-review by experienced researchers

- Rapid publication on acceptance

- Free of charge (without publication fees)

Learn more http://www.biomedpress.org/journals/
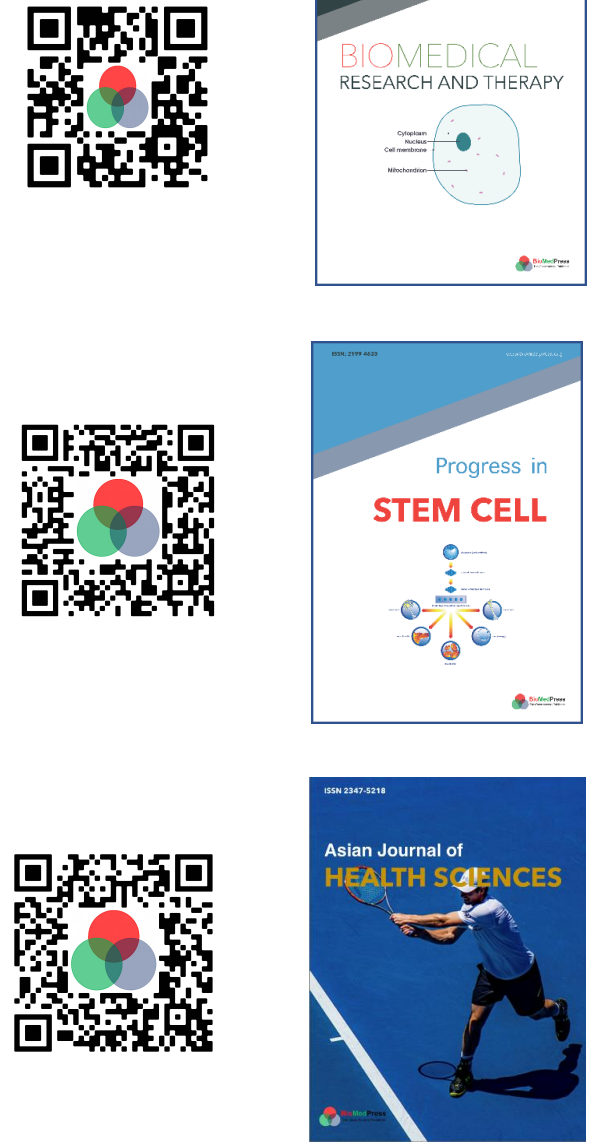

Asian Journal of Health Sciences

ISSN: 2347-5218

Indexed: Google Scholar

Acceptance Rate (2020): 72.89\%

Article Publishing Charge: Free

Submission to first editorial decision: 16.5 days

Biotechnological Research

ISSN: 2395-6763

Indexed: Google Scholar

Acceptance Rate (2020): $67.02 \%$

Article Publishing Charge: Free

Submission to first editorial decision: 28.5 days 